\title{
Growth Hormone Receptor Antisense Oligonucleotide IONIS-GHR-LRx
}

National Cancer Institute

\section{Source}

National Cancer Institute. Growth Hormone Receptor Antisense Oligonucleotide IONIS-

GHR-LRX. NCI Thesaurus. Code C162807.

An antisense oligonucleotide targ eting the growth hormone receptor (GHR;

somatotropin receptor) mRNA, with potential somatotropin-inhibiting activity. Upon subcutaneous administration, GHR antisense oligonucleotide IONIS-GHR-LRx hybridizes with GHR mRNA, which blocks translation of the GHR protein. Reduction of GHR levels in turn decreases the circulating level of insulin-like growth factor-1 (IGF-1). IGF-1 is a hormone that plays an important role in childhood growth and has anabolic effects in adults. Excess production of IGF-1 results in various disease states including acromegaly. 